\title{
Parents' Decisions to Screen Newborns for FMR1 Gene Expansions in a Pilot Research Project
}

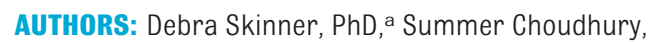
MA, ${ }^{b}$ John Sideris, PhD, a Sonia Guarda, MA, a Allen Buansi,

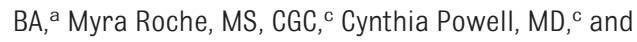
Donald B. Bailey, Jr, PhDd

aFPG Child Development Institute, ${ }^{b}$ Division of Pulmonary and Critical Care Medicine, and ${ }^{C}$ Department of Pediatrics, University of North Carolina at Chapel Hill, Chapel Hill, North Carolina; and ${ }^{d}$ RTI International, Research Triangle Park, North Carolina

\section{KEY WORDS}

newborn screening, informed consent, patient decision making, screening tools

\section{ABBREVIATIONS}

NBS-newborn screening

FXS-fragile X syndrome

RA-research assistant

FX-fragile X (FMR1 gene expansions)

Dr Skinner made substantial contributions to the conception and design, acquisition, analysis, and interpretation of data; and drafted the article for intellectual content. Ms Choudhury made substantial contributions to the acquisition, analysis, and interpretation of data; and helped draft article for intellectual content. Dr Sideris made substantial contributions to analysis and interpretation of data; and helped draft article for intellectual content. Ms Guarda made substantial contributions to the acquisition and interpretation of data; and helped revise the article for intellectual content. Mr Buansi made substantial contributions to the analysis of data and helped revise the article for intellectual content. Ms Roche and Drs Powell and Bailey made substantial contributions to the conception and design, analysis and interpretation of data; and helped draft the article for intellectual content. All authors read and approved the manuscript submitted.

www.pediatrics.org/cgi/doi/10.1542/peds.2010-3078

doi:10.1542/peds.2010-3078

Accepted for publication Feb 10, 2011

Address correspondence to Debra Skinner, PhD, FPG Child Development Institute, University of North Carolina at Chapel Hill, CB \#8040, 517 S. Greensboro St, Carrboro, NC 27510. E-mail: debra.skinner@unc.edu

PEDIATRICS (ISSN Numbers: Print, 0031-4005; Online, 1098-4275).

Copyright (C) 2011 by the American Academy of Pediatrics

FINANCIAL DISCLOSURE: The authors have indicated they have no financial relationships relevant to this article to disclose.

Funded by the National Institutes of Health (NIH).

COMPANION PAPER: A companion to this article can be found on page 1593 and online at www.pediatrics.org/cgi/doi/10.1542/ peds.2011-0677.

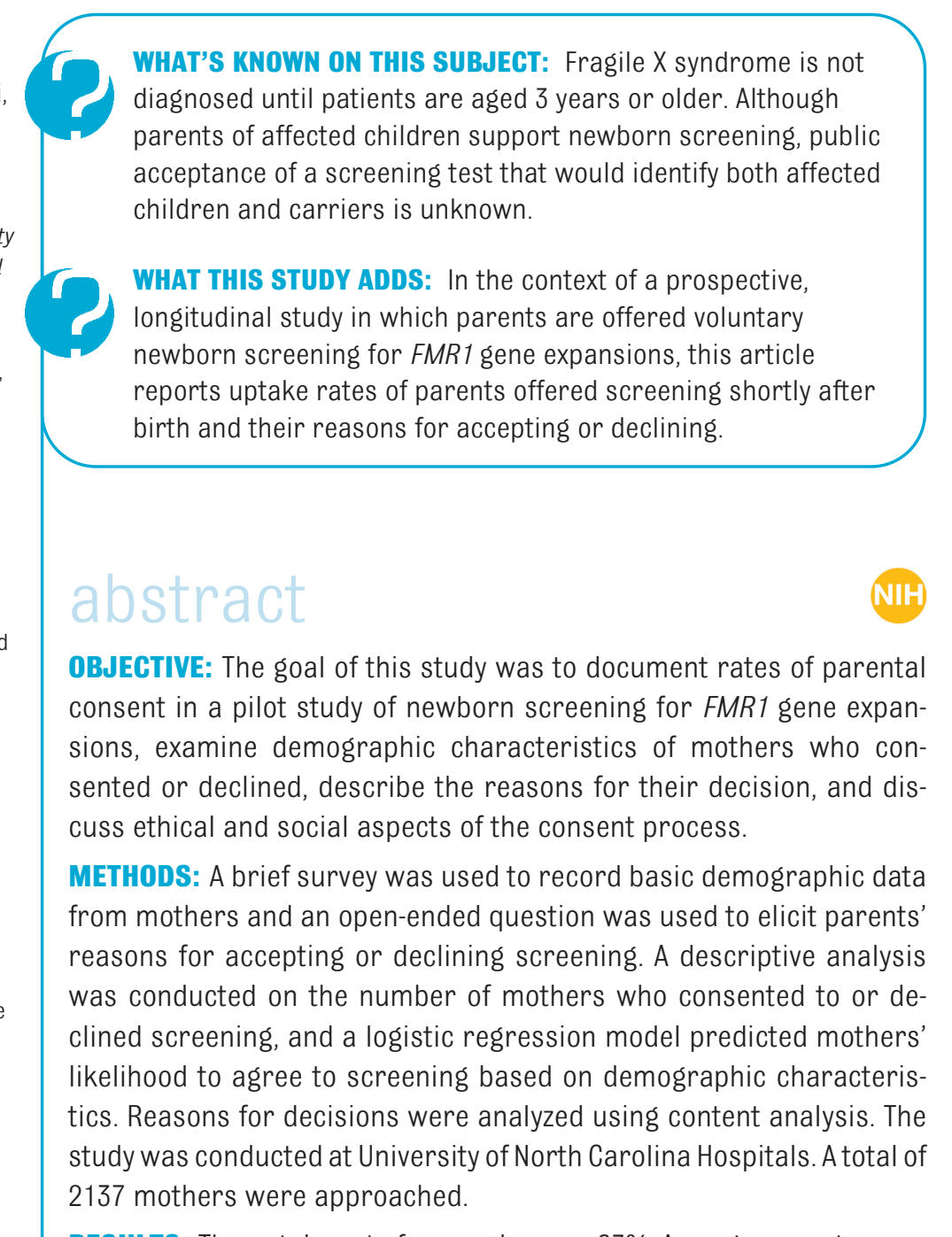

RESULTS: The uptake rate for couples was $63 \%$. Acceptance rates varied by race/ethnicity, with black respondents being less likely to accept screening. Primary reasons for accepting were "to know," "belief in research," and "the test was minimal/no risk." Reasons for declining included not wanting to know or worry, not being a good time, and issues with testing children or with genetic tests.

CONCLUSIONS: Findings demonstrate that a majority of parents accepted newborn screening for FMR1 gene expansions, but decision rates and reasons for accepting or declining varied in part as a function of race/ethnicity and in part as a function of what parents most valued or feared in their assessment of risks and benefits. Pediatrics 2011;127:e1455-e1463 
State newborn screening (NBS) programs are currently the focus of public debate and scrutiny regarding which conditions should be added to screening panels and whether parental consent should be obtained for screening and the retention of blood spots. ${ }^{1-3}$ Recent expansions of NBS and the potential for adding tests for more conditions in the future have raised several concerns, including the ethical, legal, and social implications of including conditions for which there are no medical treatments; labeling infants as asymptomatic carriers or "at-risk" individuals; and disclosing findings of uncertain medical significance, carrier status, or susceptibility to adultonset disorders. ${ }^{4-9}$ Given these concerns, screening for conditions that do not meet current NBS criteria should only be conducted as part of a research protocol with a rigorous consent process clearly discussing the risks and benefits of a positive result. ${ }^{10-12}$

Fragile $X$ syndrome (FXS), the most common inherited cause of intellectual disability, is an X-linked genetic condition that exemplifies these issues. FXS is caused by a CGG trinucleotide repeat expansion ( $>200$ repeats) of the FMR1 gene that, when methylated, causes the reduction or absence of a protein (FMRP) necessary for normal brain development and functioning. Absence of FMRP leads to the overactivation of mGluR5, a metabotropic glutamate receptor affecting synaptic plasticity. ${ }^{13}$ Males with FXS typically have moderate intellectual disability and a variety of co-occurring conditions, the most common being anxiety, inattention, hyperactivity, and autism or autistic symptoms. ${ }^{14}$ Intellectual functioning in females can range from typical cognitive abilities to moderate impairment, a spectrum largely due to $X$ inactivation. It is estimated that $\sim 1$ per 4000 males and 1 per 6000 females have the full mutation. 15,16

The FMR1 full mutation leading to FXS is maternally inherited either from a carrier of a premutation (55-200 CGG repeats) or a full mutation. The prevalence of the premutation is common, estimated at 1 per 290 to 800 in males and 1 per 129 to 259 in females. ${ }^{15,16} \mathrm{Fe}$ male carriers have an elevated risk for primary ovarian insufficiency and early menopause ${ }^{17}$; males and, to a lesser extent females, have an increased risk for fragile $X$ tremor ataxia syndrome, a debilitating neurologic impairment occurring after 50 years of age..$^{18}$ Recent animal and human studies have demonstrated that some carriers may have other neurologic or emotional problems, suggesting a broader range of risk and disability than has been previously assumed. ${ }^{14,19-22}$

The rationale for FXS NBS includes a persistently delayed age of diagno$\mathrm{sis}^{23}$; the strong support by parents of affected children ${ }^{24}$; and possible benefits for families such as prevention of the "diagnostic odyssey" and its financial and emotional costs; and the early availability of information about FXS, parents' reproductive risks, and appropriate services for the child's special needs. ${ }^{25}$ After weighing these and other benefits, an American College of Medical Genetics task force did not recommend FXS for inclusion in state NBS, ${ }^{26}$ however, primarily due to the lack of a cost-effective screening test and the absence of data on possible benefits from identification of newborns. DNA-based screening for a CGG expansion also identifies carriers, evoking a wide range of ethical, legal, and social concerns. Besides the current lack of a medical treatment for children identified with the full mutation, perhaps the most fundamental concern is triggered by the ambiguity of the risk for carriers to have develop- mental problems or adult-onset disorders such as fragile $X$ tremor ataxia syndrome and primary ovarian insufficiency. Presymptomatic identification of children could lead to a range of adverse outcomes, such as elevated rates of postpartum depression, parents' ongoing anxiety and worry about their child's future, and possible disruptions to the parent-child relationship. $2,4,11,27$

Most of these risks and benefits are not unique to FXS and apply to a wide range of other genetic conditions likely to be considered for inclusion on NBS panels. Determining whether these hypothesized risks and benefits are valid can only be accomplished by examining them in a prospective screening study. After careful deliberation of the ethical and social implications ${ }^{4}$ and based on our previous research with families of children with FXS, ${ }^{24,28}$ we designed a research project at the University of North Carolina Hospitals that offers, through a voluntary consent process, NBS for FMR1 gene expansions. Our rationale for the study was that there are multiple concerns and speculations about the risks and benefits of expanded screening but very little empirical investigation. The study uses FXS as a prototype for studying issues such as public willingness to accept screening for conditions that are not medically treatable or those that would identify newborns as carriers and/or at risk for late-onset conditions, and how families adapt to genetic information and to their identified child. ${ }^{4}$

We initiated the pilot study in February 2009 , once a cost-effective screening test was available. ${ }^{29}$ The screening test identifies both the premutation and full mutation in males and females. The study's long-term aim was to follow-up identified and matched comparison families to assess family adaptation and child development. In this article, 
we report findings on rates of parental consent, examine demographic characteristics of parents who consented or declined, describe the reasons parents gave for their decisions, and discuss ethical and social aspects of the consent process. For the sake of brevity and clarity, we use the term fragile $X(F X)$ to include both carriers (CGG repeat length of 55-200) and individuals with fragile X syndrome (FXS) (CGG repeat length $>200$ ).

\section{METHODS}

\section{Participants and Design}

A research assistant (RA) employed by the study approached mothers on the postpartum unit within 24 hours of their giving birth. Parents were given a study brochure and consent form describing the purpose of the study, the experimental screening test that detects infants with $F X$, information about the range of features expected in those who screen positive, a detailed list of the risks and benefits of a positive result, and follow-up procedures including confirmatory testing and genetic evaluation and counseling. (The information given to parents can be found at www. fpg.unc.edu/ fxnewborn/. The specific risks and benefits communicated to parents are listed in the Appendix.) RAs were trained to communicate this information in a consistent manner to all families, and were available to discuss the study in detail and answer questions. In most cases, parents had several hours to consider the study before deciding. All materials were available in Spanish, and an RA fluent in Spanish approached Spanishspeaking families. Mothers were not approached if younger than age 15 years, were experiencing stressful medical or personal circumstances, had infants in critical care for lifethreatening conditions or relinquished for adoption, or if not proficient in either English or Spanish. The institu- tional review board approved this study under 45 CFR 46.406, requiring consent from both parents "unless one parent is deceased, unknown, incompetent, or not reasonably available, or when only one parent has legal responsibility for the care and custody of the child." For consented newborns, an extra blood spot obtained at the same time as the regular NBS was placed on a separate card and sent to a Clinical Laboratory Improvement Amendmentsapproved laboratory to conduct the screening test. No additional heel stick was done for this study. Parents were informed they would receive notice of the results within 8 weeks, by letter if screened negative, and by a phone call from the medical geneticist on the research team if positive.

\section{Survey and Data Collection}

After deciding whether to enroll, parents were asked to respond to a brief survey with basic demographic data: mother's age, ethnicity/race, education, primary language, and number of previous births. An open-ended question elicited parents' reasons for their decision to accept or decline screening. Parents were not prompted to give $>1$ reason, although many did so. The RA recorded their responses verbatim.

\section{Data Analysis}

A descriptive analysis was conducted on the number of mothers who consented to or declined screening according to age, education, race/ethnicity, whether English was the primary language, and number of previous births. These variables were used to run logistic regression models to predict the mother's likelihood to agree to screening. Open-ended reasons for accepting or declining were entered into NViv08, a software program that facilitates analysis of textual data (QSR International.com). Following established procedures for content analy- sis, ${ }^{30-32}$ the first and second author independently read the first 1000 responses, and devised codes subsuming each response. This coding scheme was refined through comparison, discussion, and application of codes in an iterative process, and the final codes were then used to categorize all responses. Two coders independently coded responses and compared coding. Any discrepancies in coding were reconciled through reviewing the responses, discussion, and consensus.

\section{RESULTS}

\section{Consent Rates}

Between February 2009 and April 2010, study recruiters approached 2137 mothers. Of these, 2045 (95.7\%) were willing to hear about the study. About two thirds (67.5\%) of the 2045 consented to have their newborn screened. Because some fathers actively declined screening $(n=16)$ or failed to return a signed consent form $(n=76)$ after the mother consented, the rate of consent for couples dropped to $63 \%$. Of the 2045 mothers, 1930 filled out the brief survey, providing basic demographic information for 1381 acceptors and 549 decliners (Table 1). Of the 115 who did not fill out the brief survey, 114 were decliners.

The project was conducted at a university research and teaching hospital serving a diverse population, including lower-income families and Latino immigrants as well as university faculty and students. Of the mothers, $37 \%$ were Latino/Hispanic, almost all of whom were Spanish speakers; $43.7 \%$ were white; and $13.4 \%$ black. As for education, $44.2 \%$ had a high school education or less while $21.1 \%$ had postgraduate or professional degrees.

When looking at screening decisions by race/ethnicity alone, black mothers were less likely to agree to screening 
TABLE 1 Demographic Features of Mothers

\begin{tabular}{|c|c|c|c|}
\hline Feature & $\begin{array}{l}\text { Acceptors } \\
(n=1381)\end{array}$ & $\begin{array}{l}\text { Decliners } \\
(n=549)\end{array}$ & Test of Difference \\
\hline Mean age, y & 28.4 & 28.7 & $t=.88$ \\
\hline Marital status, \% & & & $\chi_{2}^{2}=1.59$ \\
\hline Single, never married & 39.5 & 38.1 & \\
\hline Married & 57.6 & 59.9 & \\
\hline Previously married & 2.8 & 2.0 & \\
\hline Education, \% & & & $\chi_{2}^{4}=3.74$ \\
\hline$<$ High school & 28.2 & 30.8 & \\
\hline High school degree & 15.4 & 14.6 & \\
\hline Some college & 17.1 & 17.9 & \\
\hline College degree & 17.0 & 18.2 & \\
\hline Postgraduate degree & 22.1 & 18.6 & \\
\hline Race/ethnicity, \% & & & $\chi_{2}^{3}=16.39^{a}$ \\
\hline Black & 11.8 & 17.3 & \\
\hline Latino/Hispanic & 37.0 & 37.0 & \\
\hline White & 45.9 & 37.9 & \\
\hline Other & 5.3 & 7.8 & \\
\hline Language, \% & & & $\chi_{2}^{2}=9.85^{\mathrm{a}}$ \\
\hline English & 63.6 & 59.0 & \\
\hline Spanish & 32.8 & 34.1 & \\
\hline Other & 3.6 & 6.9 & \\
\hline Gender of newborn, \% & & & $\chi_{2}^{1}=.90$ \\
\hline Male & 51.7 & 49.3 & \\
\hline Female & 48.3 & 50.7 & \\
\hline No. of live births, including newborn & & & $t=.63$ \\
\hline 1 & 38.9 & 38.8 & \\
\hline 2 & 34.4 & 32.2 & \\
\hline 3 & 16.5 & 17.7 & \\
\hline 4 & 6.4 & 5.8 & \\
\hline$>5$ & 3.8 & 5.0 & \\
\hline
\end{tabular}

a $P<.01$.

TABLE 2 Relationship Between Selected Maternal Demographic Variables and Acceptance of FXS NBS

\begin{tabular}{|c|c|c|c|}
\hline Variable & OR (SE) & $\mathrm{Cl}$ & $\chi^{2}$ \\
\hline Asian vs black & $1.27(0.37)$ & 0.72 to 2.24 & 0.67 \\
\hline Asian vs Hispanic & $0.69(0.20)$ & 0.39 to 1.22 & 1.59 \\
\hline Asian vs other & $1.99(0.87)$ & 0.85 to 4.68 & 2.49 \\
\hline Asian vs white & $0.66(0.17)$ & 0.40 to 1.08 & 2.69 \\
\hline Black vs Hispanic & $0.55(0.10)$ & 0.38 to 0.78 & $10.71^{\mathrm{a}}$ \\
\hline Black vs other & $1.57(0.61)$ & 0.74 to 3.35 & 1.36 \\
\hline Black vs white & $0.52(0.09)$ & 0.38 to 0.72 & $15.51^{b}$ \\
\hline Hispanic vs other & $2.88(1.12)$ & 1.34 to 6.18 & $7.34^{\mathrm{a}}$ \\
\hline Hispanic vs white & $0.95(0.16)$ & 0.69 to 1.31 & 0.09 \\
\hline Other vs white & $0.33(0.12)$ & 0.16 to 0.68 & $8.89^{a}$ \\
\hline Single vs married & $1.27(0.16)$ & 0.98 to 1.64 & 3.34 \\
\hline Single vs previously married & $0.78(0.28)$ & 0.38 to 1.59 & 0.48 \\
\hline Married vs previously married & $0.61(0.22)$ & 0.30 to 1.24 & 1.84 \\
\hline$<$ high school vs high school degree & $0.77(0.14)$ & 0.54 to 1.09 & 2.17 \\
\hline$<$ high school vs some college & $0.74(0.14)$ & 0.51 to 1.08 & 2.49 \\
\hline <high school vs college degree & $0.71(0.16)$ & 0.46 to 1.09 & 2.45 \\
\hline$<$ high school vs graduate degree & $0.53(0.13)$ & 0.33 to 0.84 & $7.16^{\mathrm{a}}$ \\
\hline High school degree vs some college & $0.96(0.18)$ & 0.67 to 1.39 & 0.04 \\
\hline High school degree vs college degree & $0.92(0.19)$ & 0.61 to 1.39 & 0.16 \\
\hline High school degree vs graduate degree & $0.69(0.15)$ & 0.44 to 1.06 & 2.82 \\
\hline Some college vs college degree & $0.96(0.18)$ & 0.66 to 1.38 & 0.06 \\
\hline Some college vs graduate degree & $0.71(0.14)$ & 0.48 to 1.06 & 2.83 \\
\hline College degree vs graduate degree & $0.75(0.13)$ & 0.53 to 1.04 & 2.91 \\
\hline Mother's age & $0.99(1.01)$ & 0.97 to 1.01 & .69 \\
\hline No. of live births & $0.97(1.05)$ & 0.89 to 1.06 & 0.41 \\
\hline
\end{tabular}

OR indicates odds ratio; $\mathrm{Cl}$, confidence interval.

a $P<.01$.

b $P<.001$.
(63.7\%) than Hispanic (71.6\%) or white (75.4\%) mothers. A logistic regression model to predict a mother's likelihood to agree to screening used maternal variables of ethnicity/race, marital status, education, age, and number of previous births. Results are reported in Table 2. In this model, black respondents were about half as likely to agree as either Hispanic (odds ratio: 0.55 ) or white (odds ratio: 0.52) respondents. Those classified as "other" were about one third as likely to agree as white respondents. Education was measured as a categorical variable with 5 levels: less than high school, high school, some college, college degree, and graduate degree. In general, education was positively related to willingness to participate; as education increased, so did willingness. However, only 1 of the pairwise comparisons between levels was significant: those with graduate degrees were more likely to agree to participate than those with less than a high school diploma.

\section{Reasons for Accepting or Declining}

The content analysis including categories, frequencies, and representative comments for the reasons parents gave for their decisions is reported in Table 3. The most prevalent reason, by far, given by acceptors was "to know" (71.6\%). Parents indicated they wanted to know to monitor their child's health and development, and to plan ahead. Most comments were similar to the parent who said, "Cause I believe that every test can help. I'd rather know more than less. It can give us a jump start if something is wrong, to help her get better." Almost one third cited a belief in research as a reason for consenting. For example, 1 mother wanted to participate "to further knowledge, to help with research." Another mother viewed participation as a social responsibility, saying "You can't find cures for dis- 
$n(\%)^{\mathrm{a}}$

Reasons for accepting ( $n=1288$ )

Knowing is good/there is benefit to knowing/knowing earlier is better

To contribute to research

The test is minimal risk/noninvasive/just an additional test

Participating cannot hurt/nothing to lose

$354(27.5)$

$108(8.4)$

My family has a history of problems

The screening is free

Just curious

Spouse/partner convinced me

Because the screen was offered

To provide reproductive risk information

Reasons for declining $(n=565)$

Logistics (the context, the timing is not good)

$121(21.4)$

Do not want to worry

Issues regarding testing

Do not want to know

$100(17.7)$

Do not want to be in study/not interested

It is not necessary

Little chance of having it/no family history

Spouse/partner declined or disagreed

My baby is fine/healthy

I would rather wait for symptoms to appear
Representative Responses

"More information is always a bonus. l'd rather know about stuff."

"I believe in early intervention kind of stuff. No better way to prepare your future than to know up front."

"We're happy to do it if it benefits research."

"I want to support research."

"It's non-intrusive; an additional drop of blood is not much."

"There are no risks; he's being pricked already."

"Figured it would be a good thing to do. Not much reason not to."

"I don't see any reason why I wouldn't do it."

"In our family we have these types of problems."

"I have a cousin like this with mental retardation."

"Extra screening is always a bonus, especially if it's free."

"It is good to get a free test. You won't hurt the child and it's free."

"Just curious. Better safe than sorry."

"Curiosity is a big factor for me."

"Main reason is my husband is a scientist and he knows it is important. I agree with him and believe him."

"Because it was offered. We have the opportunity."

"Why not if it's something that's offered. He'll be tested for 50 other conditions."

"We think it would be good for him to know for when he has children."

"To decide whether to have more children in the future."

"Not right now. I'm participating in lots of studies. The traffic in and out (of the room) has been non- stop."

"We're not too comfortable with it at this time. We're bombarded with a lot right now."

"Because I want to believe that everything is 0K; I don't want to worry."

"At this stage, we feel information would cause more stress than be helpful."

"The baby is tested for enough things already. Too much testing can make one paranoid."

"I'm not interested in extra testing. I had no prenatal testing either."

"At this point I don't really want to know if there's anything and I don't want to know if I passed it."

"I don't want to because I don't want to know if he has a problem."

"I'm not the study participant type."

"I'm not interested."

"No, I think the regular screening you are talking about is enough. We don't think the other is necessary."

"It's not something we're worried about. No genetic predisposition. We already have a healthy child. There's no one in our family with mental retardation."

"Neither us nor the family has this type of syndrome; we don't think she can inherit it."

"I would have liked to have done it, to know and be prepared in case he has it, but my husband doesn't want to."

"I think God made her a healthy baby. I believe she will be perfectly fine."

"She looks pretty healthy to me; I know nothing is wrong."

53 (9.4) "I would rather not know since I don't know when it will kick in. I'd rather not know and find out later when it happens."

"If he's going to have mental retardation, then we'll deal with it when it happens. There's no point in knowing now."

"Not interested because there's no cure." 
eases without doing these things. It's your social responsibility. Try to help out all you can." The only other predominant reason, given by more than one fourth of the acceptors, was that the study was noninvasive, posing minimal or no risk to the child.

Reasons for declining were more equally distributed and included not wanting to worry about the test result (21.4\%), negative feelings about testing children or genetic testing in general (19.3\%), and not wanting to know (17.7\%). About one fourth noted that the timing or context for deciding was not good. Decliners voiced the same concerns that bioethicists and others have raised about NBS. One mother said, "Knowing can cause anxiety. The chances of it happening are very small; don't know how it will unfold. Not knowing will not make you treat your child a certain way." Another mother declined "because I don't feel comfortable. I would rather not know since I don't know when it will kick in. I don't want to stress over the test results. l'd rather not know and find out later when it happens." Those who indicated a distrust of or opposition to tests in general made comments like, "I just didn't want an extra test because we didn't do any extra tests with the pregnancy," "The infant is tested for enough things already," and "Too much testing can make one paranoid."

Both an advantage and a risk of screening for FX, depending on one's perspective, is that identifying a newborn with an altered FRM1 gene provides information to parents that one of them has a substantially increased risk for having children who are either carriers or have FXS. Although this knowledge was presented as both a benefit and risk in the consent form, only 8 parents noted "to provide reproductive risk information" as a reason for accepting.

\section{DISCUSSION}

This pilot project was not designed to maximize uptake but rather to examine the extent to which parents accept or decline screening within the context of a written consent process that explicitly stresses the risks and benefits specific to learning whether their newborn has an expanded FMR1 gene. The acceptance rate of $63 \%$ is considerably lower than those reported in other NBS pilot projects ${ }^{33-35}$ and lower than the $79 \%$ rate reported in a pilot study that offered FX screening for male newborns in South Carolina. ${ }^{36} \mathrm{Ac}-$ ceptance rates are likely to vary depending on the timing, content, and extent of the consent process, whether consent is oral or written or opt in or opt out, the type of disorder, and whether treatments exist. ${ }^{35}$ In this study, the acceptance rate is not surprising considering that the screening test detects a condition with no cure, discloses carrier status for which predictive information is equivocal, and is preceded by a rigorous consent process, generally requiring both parents' consent, conducted in the hospital within 24 hours of birth. One concern about pilot studies offering informed consent for NBS is that parents may begin to question or choose to opt out of state NBS. There were no cases of that happening in this study.

In a previous article, we examined possible challenges to an informed consent process in screening for FX in the neonatal setting. ${ }^{4}$ These challenges included the ability to adequately explain the potential consequences of having FXS or of being a premutation carrier, and the possible ramifications of a positive diagnosis for the family, including confirmatory testing and genetic counseling. Although we designed educational and consent materials to convey this information, and RAs were trained to explain and discuss the study and FX in more de- tail, the reasons some parents gave, or did not give, indicate that they may not have fully understood the study or FX and its personal, familial, and social consequences. For example, the mother who indicated she consented to the screening to help to find cures for diseases may have misunderstood the purpose of the study. Parents who gave as a reason for consenting "to help my child get better" may have not understood that there is no cure or standard medical treatment or they may have been referring to earlyintervention services. Those who declined the study because the infant looked healthy or there were no problems in their family may not have understood how FX is inherited or manifests, but they may also have not wanted to consider that something could be wrong with their newborn. The lack of responses about a positive result providing information on reproductive risk or possible medical conditions in adult carriers is likely due to parents at this time focusing more on the implications of a positive diagnosis for the newborn and not what this information would mean for others. About one fourth of those who declined also indicated that the timing and context of consent were not optimal, raising the issue of the most appropriate time for consent and screening. Parents' opinions about these issues warrant additional study. We are currently conducting interviews with a subset of decliners and negatively screened acceptors to examine in more detail their evaluations of the consent process, understanding of the information presented, and reasons for their decision. We are also assessing the positive screened families to ascertain their responses and experiences related to the diagnosis.

For the most part, the reasons given by the vast majority of parents for accepting or declining suggest that they were 
assessing many of the risks and benefits of the study and were making decisions based on what they most valued, or perhaps most feared. Although acceptance rates were lower than other NBS pilot studies, almost two thirds of families consented, indicating more parental support for testing for FMR1 gene expansions in the newborn period than reported among pediatricians or genetic counselors. ${ }^{37,38}$ This is consistent with studies that indicate parents may view the benefits of expanded screening more broadly than defined by current criteria for NBS and are supportive of such screening with informed consent. ${ }^{39}$ Our findings also indicate some difference in acceptance rates according to race/ethnicity, with black respondents somewhat less likely to consent to screening. This may be due to mistrust rising from the historical legacy of medical and genetic research in the United States with blacks ${ }^{40-42}$ or to a different valuing of the benefits and risks of screening. We cannot answer this question from our data but acknowledge that the role of race/ethnicity versus cultural differences in medical decision making is complex and requires additional investigation.

During the course of this pilot project, studies that could fundamentally change the rationale and need for NBS have been reported. These include studies showing that compounds reducing excess glutamate signaling substantially improve functioning in fmr1 knockout mice ${ }^{43}$ and Drosophila. ${ }^{44}$ In addition, human clinical trials with adolescents and adults with FXS are now testing the effects of medications known to reduce mGluRactivated translation. ${ }^{45-48}$ Because FXS affects neurologic processes necessary for normal development and learning in the early years, these treatments (if shown to be safe and effective for young children) would likely be most effective if given early. However, the fact that carriers would be identified suggests that parent consent for screening for FXS will still be required. In anticipation of this scenario, more research is needed comparing and contrasting alternative strategies and times for informing families so that they can make informed decisions about having their child screened.

\section{CONCLUSIONS}

Our findings contribute empirical data on public willingness to participate in NBS for FMR1 gene expansions. Results indicate that almost two thirds of parents support FXS screening in the neonatal context, and parents' reasons for accepting or declining suggest some understanding of the benefits and risks of the study. As for most research projects, we cannot determine if truly informed consent was obtained but have demonstrated that although not the ideal time or place, it is possible to obtain informed consent in a neonatal context. Alternative consent strategies need to be considered but of ultimate importance will be the impact of the information on families who receive a positive diagnosis, including those individuals who may be asymptomatic carriers.

\section{APPENDIX: RISKS AND BENEFITS LISTED IN CONSENT FORM AND BROCHURE}

\section{Benefits to Infants Identified as} Having FXS or Being a Carrier May Include:

The diagnostic testing, genetic counseling, clinical evaluation, and referrals provided by the study.

Eligibility for certain learning and therapeutic services that may be helpful to the infant.

Alerting parents to the future health or learning problems the infant may have.
Preparing parents to raise a child with special needs.

\section{Benefits to Parents of Infants}

Identified as Having FXS or Being a Carrier May Include

Saving financial and emotional costs of many trips to physicians to find out the cause of their child's problems.

Getting the early-intervention services the child may need.

Information that they and their relatives may be at risk for having children with FXS.

Getting support services that may be helpful to them.

\section{Risks of Being in the Study}

There may be a small emotional risk; you might worry about whether the infant's screening in the study will show a need for more testing.

Learning that one's infant has FXS may bring about feelings of grief, a sense of Ioss, worry, or anxiety. It may cause some stress in the family.

Learning that one's infant has FXS may cause parents to worry about what the condition will mean for the infant and family.

If an infant has the gene change for FXS, it means that one of the parents also has the gene change. Parents may feel bad about passing on that gene change. They may worry that other children or family members need testing.

There may be some stigma associated with learning there is an inherited genetic condition in one's family.

Although there are laws to protect genetic information, you may worry about how others could use this information. Discrimination against your family or child by insurance companies, employers, or schools could be possible.

Finally, although unlikely, the study screening test result could be wrong. It 
may show that infants need more testing when they do not or it may not find infants with FXS. If your infant has health or developmental problems later, he or she may need diagnostic testing for FXS.

\section{ACKNOWLEDGMENTS}

The Fragile $X$ Newborn Screening Study is supported by the Eunice Kennedy Shriver National Institute for

\section{REFERENCES}

1. Pelias MK, Markward NJ. Newborn screening, informed consent, and future use of archived tissue samples. Genet Test. 2001; 5(3):179-185

2. Baily MA, Murray TH. Ethics and Newborn Genetic Screening: New Technologies, New Challenges. Baltimore, MD: The Johns Hopkins University Press; 2009

3. Grosse SD, Boyle CA, Kenneson A, Khoury MJ, Wilfond BS. From public health emergency to public health service: the implications of evolving criteria for newborn screening panels. Pediatrics. 2006;117(2): 923-929

4. Bailey DB Jr, Skinner D, Davis A, Whitmarsh I, Powell C. Ethical, legal, and social concerns about expanded newborn screening: fragile $X$ syndrome as a prototype for emerging issues. Pediatrics. 2008;121(3). Available at: www.pediatrics.org/cgi/ content/full/121/3/e693

5. Botkin JR. Research for newborn screening: developing a national framework. Pediatrics. 2005;116(4):862-871

6. Botkin JR, Clayton EW, Fost NC, et al. Newborn screening technology: proceed with caution. Pediatrics. 2006;117(5):1793-1799

7. Kerruish NJ, Robertson SP. Newborn screening: new developments, new dilemmas. J Med Ethics. 2005;31 (7):393-398

8. Taylor HA, Wilfond BS. Ethical issues in newborn screening research: lessons from the Wisconsin cystic fibrosis trial. J Pediatr. 2004;145(3):292-296

9. Timmermans S, Buchbinder M. Patients-inwaiting: living between sickness and health in the genomics era. J Health Soc Behav. 2010;51(4):408-423

10. Hill MK, Archibald AD, Cohen J, Metcalfe SA. A systematic review of population screening for fragile X syndrome. Genet Med. 2010; 12(7):396-410

11. Ross LF. Screening for conditions that do not meet the Wilson and Jungner criteria:
Child Health and Human Development (P30 HD003110-S1); the National Human Genome Research Institute's Ethical, Legal, and Social Implications Research Program (5P50HG004488); Centers for Disease Control and Prevention in conjunction with the Association for Prevention Teaching and Research (Cooperative Agreement No. U50/CCU300860, Project TS-1470); the National New-

the case of Duchenne muscular dystrophy. Am J Med Genet A. 2006;140 (8):914-922

12. Ross L. Ethical and policy issues in newborn screening: historical, current, and future developments. Neoreviews. 2009;10(2): e71-e81

13. Ronesi JA, Huber KM. Metabotropic glutamate receptors and fragile $\mathrm{x}$ mental retardation protein: partners in translational regulation at the synapse. Sci Signal. 2008; 1(5):pe6

14. Bailey DB Jr, Raspa M, Olmsted M, Holiday DB. Co-occurring conditions associated with FMR1 gene variations: findings from a national parent survey. Am J Med Genet $A$. 2008;146A(16):2060-2069

15. Hagerman PJ. The fragile X prevalence paradox. J Med Genet. 2008;45(8):498-499

16. Crawford DC, Acuna JM, Sherman SL. FMR1 and the fragile $X$ syndrome: human genome epidemiology review. Genet Med. 2001;3(5): 359-371

17. Sherman SL. Premature ovarian failure in the fragile $X$ syndrome. Am J Med Genet. 2000;97 (3):189-194

18. Hagerman PJ, Hagerman RJ. Fragile X-associated tremor/ataxia syndrome (FXTAS). Mental Retard Dev Disabil Res Reviews. 2004;10(1):25-30

19. Bourgeois JA, Coffey SM, Rivera SM, et al. A review of fragile $X$ premutation disorders: expanding the psychiatric perspective. J Clin Psychiatry. 2009;70(6):852-862

20. Boyle L, Kaufmann WE. The behavioral phenotype of FMR1 mutations. Am J Med Genet C Semin Med Genet. 2010;154C(4):469-476

21. Chonchaiya W, Utari A, Pereira GM, Tassone F, HessI D, Hagerman RJ. Broad clinical involvement in a family affected by the fragile $X$ premutation. J Dev Behav Pediatr. 2009; 30(6):544-551

22. Cunningham CL, Martinez Cerderno V, Navarro Porras E, et al. Premutation CGGrepeat expansion of the Fmr1 gene impairs born Screening and Genetics Resource Center, a cooperative agreement between the Maternal and Child Health Bureau, Genetic Services Branch and the Department of Pediatrics, University of Texas Health Science Center at San Antonio; Health Resources and Services Administration (U32-MC00148); and the National Center of Research Resources, National Institutes of Health (UL1RR025747).

mouse neocortical development. Hum Mol Genet. 2011;20(1):64-79

23. Bailey DB Jr, Raspa M, Bishop E, Holiday D. No change in the age of diagnosis for fragile $X$ syndrome: findings from a national survey. Pediatrics. 2009;124(2):527-533

24. Skinner D, Sparkman KL, Bailey DB Jr. Screening for fragile $X$ syndrome: parent attitudes and perspectives. Genet Med. 2003; 5(5):378-384

25. Bailey DB Jr, Skinner D, Warren SF. Newborn screening for developmental disabilities: Reframing presumptive benefit. Am J Public Health. 2005;95(11):1889-1893

26. Watson MS, Lloyd-Puryear MA, Mann MY, Rinaldo P, Howell RR. Newborn screening: toward a uniform screening panel and system. Genet Med. 2006;8(5 suppl):12S-252S

27. Wilfond BS, Parad RB, Fost N. Balancing benefits and risks for cystic fibrosis newborn screening: implications for policy decisions. J Pediatr. 2005;147(3 suppl): S109-S113

28. Bailey DB Jr, Skinner D, Sparkman KL. Discovering fragile $X$ syndrome: family experiences and perceptions. Pediatrics. 2003; 111(2):407-416

29. Tassone F, Pan R, Amiri K, Taylor AK, Hagerman PJ. A rapid polymerase chain reactionbased screening method for identification of all expanded alleles of the fragile $X$ (FMR1) gene in newborn and high-risk populations. J Mol Diagn. 2008;10(1):43-49

30. Bernard HR, Ryan G. Analyzing Qualitative Data: Systematic Approaches. Thousand Oaks, CA: Sage Publications; 2010

31. Patton M. Qualitative Research and Evaluation Methods. 3rd ed. Thousand Oaks, CA: Sage Publications; 2002

32. Skinner D, Rodriguez P, Bailey DB. Qualitative analysis of Latino parents' religious interpretations of their child's disability. J Early Interv. 1999;22 (4):271-285

33. Comeau AM, Levin DE. Population-based re- 
search within a public health service. In: Baily MA, Murray TH, eds. Ethics and Newborn Genetic Screening: New Technologies, New Challenges. Baltimore, MD: The Johns Hopkins University Press; 2009:274-291

34. Feuchtbaum L, Lorey F, Faulkner L, et al. California's experience implementing a pilot newborn supplemental screening program using tandem mass spectrometry. Pediatrics. 2006;117 (5 pt 2):S261-S269

35. Ross LF, Acharya K. Policy considerations in designing a fragile $X$ population screening program. Genet Med. 2008;10(10):711-713

36. Saul RA, Friez M, Eaves $K$, et al. Fragile X syndrome detection in newborns-pilot study. Genet Med. 2008;10(10):714-719

37. Acharya K, Ackerman PD, Ross LF. Pediatricians' attitudes toward expanding newborn screening. Pediatrics. 2005;116(4): e476

38. Hiraki S, Ormond KE, Kim K, Ross LF. Attitudes of genetic counselors towards ex- panding newborn screening and offering predictive genetic testing to children. Am J Med Genet A. 2006;140 (21):2312-2319

39. Campbell E, Ross LF. Parental attitudes regarding newborn screening of PKU and DMD. Am J Med Genet A. 2003;120A(2): 209-214

40. Corbie-Smith G, Thomas SB, St George DM. Distrust, race, and research. Arch Intern Med. 2002;162(21):2458-2463

41. Corbie-Smith G, Thomas SB, Williams MV, Moody-Ayers S. Attitudes and beliefs of African Americans toward participation in medical research. J Gen Intern Med. 1999; 14(9):537-546

42. Furr LA. Perceptions of genetics research as harmful to society: differences among samples of African-Americans and European-Americans. Genet Test. 2002;6(1): 25-30

43. de Vrij FM, Levenga J, van der Linde HC, et al. Rescue of behavioral phenotype and neuro- nal protrusion morphology in Fmr1 K0 mice. Neurobiol Dis. 2008;31(1):127-132

44. Chang S, Bray SM, Li Z, et al. Identification of small molecules rescuing fragile $X$ syndrome phenotypes in Drosophila. Nat Chem Biol. 2008;4(4):256-263

45. Berry-Kravis E, Sumis A, Hervey C, et al. Open-label treatment trial of lithium to target the underlying defect in fragile $X$ syndrome. J Dev Behav Pediatr. 2008;29(4): 293-302

46. Berry-Kravis E, HessI D, Coffey S, et al. A pilot open label, single dose trial of fenobam in adults with fragile $X$ syndrome. J Med Genet. 2009;46(4):266-271

47. Paribello C, Tao L, Folino A, et al. Open-label add-on treatment trial of minocycline in fragile X syndrome. BMC Neurol. 2010;10:91

48. Wetmore DZ, Garner CC. Emerging pharmacotherapies for neurodevelopmental disorders. J Dev Behav Pediatr. 2010;31(7): 564-581 